\title{
PENGEMBANGAN AUTHENTIC ASSESSMENT SEBAGAI FUNGSI PENILAIAN FORMATIF PADA PEMBELAJARAN IPS DI KELAS IV SD
}

\author{
${ }^{1}$ Nugroho, ${ }^{2}$ Yatim Riyanto, ${ }^{3}$ Suhanadji \\ ${ }^{1}$ Mahasiswa Program Pascasarjana, Prodi Pendidikan Dasar, Universitas Negeri Surabaya, \\ ${ }^{2 \& 3}$ Dosen Pascasarjana, Prodi Pendidikan Dasar, Universitas Negeri Surabaya \\ e-mail: nugrohoklasik@gmail.com
}

Received : Juli 2017

Reviewed: Agustus 2017

Accepted : September 2017

Published : September 2017

\section{ABSTRACT}

The objective of this research is to analyze the development results of a valid, reliable, and practical assessment tools in Authentic Assessment as a Function of Formative Assessment In social studies lesson of fourth grade elementary school student. This research is a development research. The development model used in this study is 4D, namely: Define, Design, Develop and Disseminate which refers Thiagarajan development model (1974). The subjects of this research is students of class IV SDN 2 Wonoyoso and SDN Pandanlor Kebumen regency, Central Java. The Product of Authentic Assessment are Scenario Learning, Learning tasks, Instrument of Rating Attitudes, Knowledge, and Skills. The results of this study indicate that the product is the development of Authentic Assessment as a function of formative assessment has (1) validity, (2) reliability, and (3) good practicality when used in social studies lesson in fourth grade elementary school student Semester II, with the theme my environment.

Keywords: Authentic Assessment, Formative Assessment, Social Study.

\section{ABSTRAK}

Tujuan Penelitian ini adalah untuk menganalisis hasil pengembangan Authentic Assessment Sebagai Fungsi Penilaian Formatif Pada Pembelajaran IPS di kelas IV SD yang valid, reliabel, dan praktis. Penelitian ini merupakan penelitian pengembangan. Model pengembangan yang digunakan dalam penelitian ini adalah 4D, yaitu: Define, Design, Develop, dan Disseminate yang merujuk pada model pengembangan Thiagarajan (1974). Subjek penelitian ini adalah siswa kelas IV SDN 2 Wonoyoso dan SDN Pandanlor Kabupaten Kebumen Jawa Tengah. Produk Authentic Assessment yang dihasilkan meliputi Skenario Pembelajaran, Tugas-tugas Pembelajaran, Instrumen Penilaian Sikap, Pengetahuan, dan Keterampilan. Hasil penelitian ini menunjukkan bahwa Produk berupa pengembangan Authentic Assessment sebagai fungsi penilaian formatif memiliki (1) validitas, (2) reliabiliitas, dan (3) kepraktisan yang baik apabila digunakan pada pembelajaran IPS di Kelas IV SD Semester II, dengan tema Lingkunganku.

Kata Kunci: Hasil belajar, IPS, komik, media pembelajaran, pengembangan.

\section{PENDAHULUAN}

Salah satu 8 (delapan) Standar Nasional Pendidikan adalah Standar Penilaian sebagaimana termaktub dalam Peraturan Pemerintah (PP) Nomor 19 Tahun 2005 tentang Standar Nasional Pendidikan, sebagaimana telah diubah dengan Peraturan Pemerintah Nomor 32 Tahun 2013 tentang Perubahan Atas Peraturan Pemerintah (PP) Nomor 19 Tahun 2005 tentang Standar Nasional Pendidikan.
Assessment atau biasa dikenal dengan istilah penilaian merupakan bagian yang tidak terpisahkan dari perencanaan maupun pelaksanaan proses pembelajaran yang dirancang oleh pendidik. Menurut Kemp (1990) assessment memiliki porsi yang sejajar dalam pelaksanaan pendidikan di kelas.

Mengkaji assessment tidak sama dengan mempelajari teknik membuat soal tes semata, karena assessment lebih dari sekedar membuat soal dan menilai 
siswa. Assessment merupakan kegiatan mengumpulkan informasi demi tercapainya perkembangan maksimal peserta didik.

Salah satu hambatan pelaksanaan kurikulum 2013 di tingkat nasional diketahui pada proses assessment pembelajarannya yang banyak dikeluhkan guru. Seperti dilansir dalam portal berita daring liputan6 pada tanggal 21 Juli 2014, dalam reportase tersebut dikatakan bahwa M. Nuh, Menteri Pendidikan dan Kebudayaan RI Periode 2009-2014 mengakui banyak keluhan yang disampaikan para guru, khususnya cara memberikan penilaian sikap dan kreativitas anak secara otentik. Kemudian pada salah satu hasil kajian Kementrian Pendidikan dan Kebudayaan di semester kedua Tahun 2014, tercatat bahwa metode penilaian (pada Kurikulum 2013) sangat kompleks dan menyita waktu sehingga membingungkan guru dan mengalihkan fokus dari memberi perhatian sepenuhnya pada siswa. Keluhan dan opini praktisi, dalam hal ini guru mengenai kesulitan dalam penilaian pada Kurikulum 2013 menjadi salah satu sorotan di beberapa media (Tempo, 24 November 2014), baik yang bersifat lokal maupun nasional.

Berdasarkan pengalaman peneliti sendiri selama mengikuti Diklat Kurikulum 2013 di tingkat Kabupaten Kebumen pada tahun 2014, ketika memasuki penyampaian materi penilaian, banyak peserta diklat yang belum paham dan belum yakin akan melaksanakan penilaian tersebut dengan baik. Kemudian berdasarkan hasil wawancara dengan guru-guru di lapangan, setelah kembali kepada Kurikulum Tingkat Satuan Pendidikan 2006, mereka lebih merasa senang karena tidak terbebani dengan banyaknya aspek yang harus dinilai pada siswa, seperti diketahui bersama bahwa pada Kurikulum 2013 guru diberi kewajiban untuk menilai empat Kompetensi Inti (Spiritual, Sosial, Pengetahuan, dan Keterampilan).

Secara teoritis, Kurikulum 2013 menghendaki penilaian yang tidak hanya sebatas produk dan tertulis objektif. Ada kesamaan acuan penialaian antara KBK 2004, KTSP 2006 dan Kurkulum 2013, yakni sama-sama beracuan pada kriteria. Penting diketahui bahwa kriteria yang dimaksud adalah mengacu pada karakter, dan melihat perbedaan masing-masing siswa sebagai sebuah keunikan dan sesuatu yang tidak bisa dibandingkan dalam peringkat ranking. Kriteria tersebut dapat berupa batas kriteria minimal yang telah ditetapkan sebelum pengukuran dan bersifat mutlak (Uno \& Koni, 2013)

Jika dilihat paparan ini sebagai sebuah masalah, peneliti bermaksud mengajukan sebuah produk assessment sebagai solusi. Spesifikasi dasar produk tersebut antara lain: Dilihat dari fungsi, assessment yang dibuat tergolong penilaian formatif, dalam arti sebagai alat pemerolehan informasi dan umpan balik dalam pembelajaran terkait kemampuan siswa.

Diketahui bahwa salah satu bentuk assessment adalah assessment formatif yang dapat berwujud sebuah sistem. Dalam penilaian formatif siswa dilibatkan, sehingga mengetahui aturan dalam penilaian dan pemerolehan informasi dari dirinya. Mengenal Assessment formatif, tidak jarang juga para ahli yang memasangkannya dengan assessment sumatif. Kajian itu tidak membahas kedikotomian dua domain dan kewenangan jenis Assessment-assessment tersebut. Assessment formatif sendiri telah mengalami perubahan paradigma dan arah penggunaanya. Para pengembang kurikulum sendiri banyak mengkaji dan terus mendefinisikan hal ini menjadi sesuatu yang lebih mudah dipahami dan operasional (Popham W. J., 2008). Dilihat dari bentuknya assessment yang diproduksi peneliti ini merupakan sebuah Authentic Assessment. Sesuai Permendikbud No. 53 Tahun 2015 yang dimaksud Penilaian otentik adalah pendekatan penilaian yang menghendaki peserta didik menampilkan sikap, menggunakan pengetahuan dan keterampilan yang diperoleh dari pembelajaran dalam situasi yang sesungguhnya (dunia nyata). Bentuk penilaian yang menghendaki peserta didik menampilkan sikap, menggunakan pengetahuan dan keterampilan yang diperoleh dari pembelajaran dalam melakukan tugas pada situasi yang sesungguhnya. Tertulis juga pada Permendikbud tersebut bahwa Kurikulum 2013 merekomendasikan penggunaan penilaian autentik (authentic assessment). Secara paradigmatik penilaian autentik memerlukan perwujudan pembelajaran autentik (authentic instruction) dan belajar autentik (authentic learning). Hal ini diyakini bahwa penilaian autentik lebih mampu memberikan informasi kemampuan peserta didik secara holistik dan valid.

Memperhatikan penilaian pada Kurikulum 2013, salah satu penekanan yang diberikan adalah pada pendekatan authentic assessment. Sebenarnya hal ini bukan sesuatu yang instant diberikan, namun dalam kurikulum sebelumnya, Kurikulum Tingkat Satuan Pendidikan (KTSP), authentic assessment sudah diberi ruang untuk diolah dan diimplementasikan dalam pembelajaran. Namun seperti yang dikatakan Kunandar (2013: 35), bahwa implementasi penilaian autentik tersebut belum berjalan secara optimal. Maka melalui Kurikulum 2013 ini penilaian autentik menjadi penekanan yang serius dalam penilaian yang dilakukan oleh guru.

Begitu banyak strategi pembelajaran yang menjadi pilihan dalam Pembelajaran Ilmu Pengetahuan Sosial 
(IPS), tetapi sedikit yang mengkaji tentang bagaimana assessment yang ideal. Assessment diperlukan sebagai dasar perencanaan rancangan dan strategi pembelajaran di kelas. IPS sebagai pembelajaran yang membawa misi sebagai pendidikan nilai bagi siswa, tidak hanya melihat kemampuan kognitif siswa semata. Aspek sikap dan nilai harus ditekankan agar pembelajaran sesuai tuntutan kurikulum. IPS di tuntut berperan yang cukup besar dalam membentuk karakter kuat dalam peran sertanya hidup bermasyarakat. Pembelajaran IPS di Sekolah Dasar memegang peranan penting dalam memberikan pondasi dasar bagi siswa untuk menerapkan nilai-nilai karakter bangsa. Selain itu Pembelajaran IPS di SD diharapkan dapat memberikan landasan filosofi dalam kehidupan berbangsa dan bernegara para peserta didik.

Berdasarkan kesenjangan-kesenjangan di atas, maka peneliti mencoba melakukan pengembangan sebuah produk Authentic Assessment sebagai pelaksanaan fungsi dari penilaian formatif pada pembelajaran IPS di Kelas IV SD.

\section{TINJAUAN PUSTAKA}

Perspektif Kurikulum 2013 mengenai Penilaian Autentik (Authentic Assessment) bisa dilihat dalam Lampiran Permendikbud No. 66 Tahun 2013 mengenai Standar Penilaian Pendidikan. Dalam Kurikulum 2013, Authentic Assessment diupayakan untuk dilaksanakan dalam melaksanakan penilaian, mengingat karakteristik Authentic Assessment sendiri yang sangat sesuai dengan filosofi Kurikulum 2013. Karakteristik penilaian tersebut antara lain (1) belajar tuntas, (2) autentik, (3) berkesinambungan, (4) variatif, dan (5) berdasarkan acuan kriteria. Selain itu, pada penjelasan menganai mekanisme dan prosedur penilaian Kurikulum 2013 juga disebutkan bahwa Penilaian hasil belajar dilakukan dalam bentuk penilaian otentik, penilaian diri, penilaian projek, ulangan harian, ulangan tengah semester, ulangan akhir semester, ujian tingkat kompetensi, ujian mutu tingkat kompetensi, ujian sekolah, dan ujian nasional.

Assessment adalah sebuah proses. Data dikumpulkan sesuai situasi. Kemudian dianalisis dan hasilnya biasa digunakan diberikan pada seseorang (guru) dan digunakan. Secara alternative, hasilnya dapat digunakan saat itu juga. Pada bidang pendidikan assessment memiliki banyak tujuan dan tingkatan. Hal ini dapat diulas dari rancangan guru untuk membantu siswa berubah.

Assessment adalah proses dimana bukti diperoleh melalui hasil penanyaan khusus seperti tes dan survei, dan digunakan untuk menentukan hasil berdasarkan temuan metode tersebut. Ha ini dapat juga menjelaskan status atau nilai dari suatu peristiwa, hal atau kemampuan seseorang berdasarkan kinerja maupun tempat.

Dalam konteks pendidikan, assessment adalah: (1) Sebuah metode inkuiri untuk menentukan tingkat pembelajaran. (2) Sebuah metode untuk memperoleh dan mengumpulkan umpan balik yang penting. (3) Proses mengevaluasi siswa dalam konteks pendidikan. (4) Proses mendokumentasikan pengetahuan, keterampilan, sikap dan keyakinan siswa. (5) Sebuah pendekatan dan teknik pengajaran yang esensial. (6) Sebuah proses yang bersifat siklikal dan berkesinambungan untuk mengevaluasi proses belajar mengajar. (7) Sebuah metode untuk menentukan bagaimana proses belajar mengajar terbaik yang seharusnya berlangsung. (8) Sebuah alat diagnostik dan evaluatif (Rayment, 2006).

Tidak semua assessment berguna dan dibutuhkan. Terlalu ketat atau berlebihan menganalisis performa dapat memiliki efek negatif pada siswa. Untuk membuat proses yang positif, penting untuk berpikir tentang apa yang ingin Anda capai untuk diri sendiri dan siswa selama evaluasi Anda (Rayment, 2006).

Indikator Assessment yang Efektif, yaitu (1) Mengevaluasi sejauh mana tingkat penempatan pembelajaran; (2) Merupakan bagian penting dari proses pembelajaran bagi guru dan peserta didik; (3) Berperan sebagai suatu proses yang sistematis untuk mendapatkan petunjuk; (4) Mendorong pembelajaran yang efektif bila digunakan dengan cara yang tepat; (5) Menentukan langkah yang diperlukan untuk melanjutkan proses belajar mengajar selanjutnya; (6) Menawarkan cara yang positif untuk menguatkan bakat, kemampuan dan pemahaman; (7) Memiliki berbagai tujuan: memungkinkan baik guru dan peserta didik untuk melihat tingkat pencapaian dan hal yang perlu ditingkatkan; (8) Terjadi dalam banyak bentuk: misalnya bisa lisan, tertulis, kolaboratif, pribadi dan spontan antara variasi lain, tergantung pada keadaan; (9) Membantu guru untuk memberikan pelajaran yang akurat dan informatif dan umpan balik.

Authentic Assessment dalam pelaksanaan pembelajaran meliputi pengasesan dalam aspek sikap, pengetahuan, dan keterampilan. Dalam panduan penilaian pembelejaran yang dirilis Kemdikbud Tahun 2015 (sebagai lampiran Permendikbud no. 53 Tahun 2015), Mekanisme penilaian pembelajaran dimulai dengan (1) melakukan perancangan strategi penilaian oleh pendidik dilakukan pada saat penyusunan rencana pelaksanaan pembelajaran (RPP) berdasarkan silabus. (2) Penilaian Hasil Belajar oleh Pendidik dilakukan untuk memantau proses, kemajuan belajar, dan perbaikan hasil belajar melalui penugasan dan pengukuran pencapaian satu atau lebih Kompetensi Dasar. 
(3) Penilaian aspek sikap dilakukan melalui observasi/pengamatan sebagai sumber informasi utama dan pelaporannya menjadi tanggungjawab wali kelas atau guru kelas. (4) Hasil penilaian pencapaian sikap oleh pendidik disampaikan dalam bentuk predikat atau deskrips. (5) Penilaian aspek pengetahuan dilakukan melalui tes tertulis, tes lisan, dan penugasan sesuai dengan kompetensi yang dinila. (6) Penilaian keterampilan dilakukan melalui praktik, produk, proyek, portofolio, dan/atau teknik lain sesuai dengan kompetensi yang dinilai. (7) Hasil penilaian pencapaian pengetahuan dan keterampilan oleh pendidik disampaikan dalam bentuk angka dan/atau deskripsi. Adapun (8) peserta didik yang belum mencapai KKM harus mengikuti pembelajaran remedi.

Ada lima potensi kebaikan penerapan penilaian formatif, yaitu (1) Untuk membuat pengaturan pembelajaran dengan segera (2) Untuk membuat pengaturan pembelajaran jangka pendek dan panjang (3) Untuk membuat pengaturan pembelajaran yang merata kesempatannya (4) Untuk membuat pengaturan taktik belajar (5) Untuk meningkatkan perubahan iklim kelas (Popham, 2011).

Dapat digunakan untuk memantau kemajuan sosial, akademik dan perilaku.

Dari beberapa pendapat di atas, dapat disimpulkan bahwa Authentic Assessment merupakan assessment belajar yang merujuk pada situasi atau konteks "dunia nyata," yang menantang para siswa menggunakan apa yang telah mereka pelajari, memerlukan berbagai macam pendekatan untuk memecahkan masalah dan memberikan kemungkinan bahwa satu masalah bisa mempunyai lebih dari satu pemecahan. Dengan kata lain, Authentic Assessment memonitor dan mengukur kemampuan siswa dalam bermacam-macam kemungkinan pemecahan masalah yang dihadapi dalam situasi atau konteks dunia nyata.

Asesmen membutuhkan strategi atau cara supaya dapat dimanfaaatkan sesuai fungsinya. Salah satu strategi menilai siswa yaitu melalui Authentic Assessment, cara tersebut merupakan strategi assessment yang mengukur keseharian siswa (Ibrahim, 2005: 54), di dalamnya mencakup sub berupa jurnal siswa, portofolio, dan assessment diri siswa. Melengkapai definisi di atas, Authentic Assessment juga disebut penilaian sebenarnya, yaitu sebuah proses pengumpulan berbagai data yang bisa memberikan gambaran perkembangan belajar siswa (Riyanto, 2009: 175). Senada, Stringer (2010: 130) mengatakan bahwa Authentic assessment provides meaningful ways for students to demonstrate their understanding of acquired knowledge by selecting from a choice of activities that replicate challenging, real-world tasks. Artinya kurang lebih, Authentic Assessment menyajikan cara yang bermakna bagi siswa mendemonstrasikan pemahaman dari pemerolehan pengetahuan melalui seleksi dari pilihan kegiatan-kegiatan yang menantang, tugas nyata.

\section{METODE}

Penelitian ini dilakukan untuk menghasilkan instrumen penilaian yang sesuai diterapkan dalam pembelajaran IPS di Kelas IV SD. Penelitian ini juga dirancang untuk mengembangkan instrumen Authentic Assessment sebagai fungsi dari penilaian formatif yaitu dengan menggali feed-back dan feed-up yang diupayakan dapat meningkatkan kualitas pembelajaran di kelas.

Sesuai dengan tujuan penelitian dan sifat masalah dalam penelitian maka metode yang digunakan dalam penelitian ini yaitu metode penelitian Reseach And Development ( $R$ and $D$ ). Produk yang dihasilkan dalam penelitian ini adalah berupa perangkat Authentic Assessment sebagai fungsi penilaian formatif untuk yang valid, reliabel, dan praktis.

Model pengembangan yang digunakan dalam penelitian ini adalah 4D, yaitu: Define, Design, Develop, dan Disseminate, yang diterjemahkan menjadi model 4P, yaitu: Pendefinisian, Perancangan, Pengembangan, dan Penyebaran. Adapun langkah-langkah tersebut dirujuk pada model pengembangan Thiagarajan (1974). Sebagai modifikasi dan melihat kemampuan serta kapasitas peneliti saat ini, langkah 4D tersebut akan disesuaikan menjadi 3D, dengan meniadakan langkah Disseminate. Penelitian ini menggunakan rancangan one group pre test and posttest (Riyanto, 2007: 127), yang mana perlakuan hanya diberikan pada satu kelompok tanpa menggunakan kelompok pembanding, menggunakan pretes di awal, kemudian dilihat hasilnya melalui posttest.

\section{HASIL DAN PEMBAHASAN}

Langkah pertama dalam tahapan penelitian adalah pendefinisian, kegiatan ini berupaya untuk mempertegas batasan-batasan penelitian, data apa saja yang diperlukan, dan instrumen pembelajaran apa yang dibutuhkan. Kemudian, setelah format penelitian sudah terfokus, langkah selanjutnya adalah merancang produk. Produk yang dihasilkan pada penelitian ini adalah (1) Skenario pembelajaran yang dituangkan dalam Rencana Pembelajaran, (2) Tugas-tugas pembelajaran yang dituangkan dalam Lembar Kegiatan Siswa (LKS, dan juga alat penilaian yang terdiri dari (3) penilaian sikap, (4) pengetahuan, dan (5) keterampilan. 
Setelah tahap perancangan mengahsilkan produk berupa draft hasil perancangan, kemudian draft tersebut naik pada tahap pengembangan. Langkah awal dari pengembangan adalah proses validasi. Validator pada penelitian ini adalah dua orang akademisi, yang pertama adalah Prof. Dr. Rusijono, M.Pd., Guru Besar Universitas Negeri Surabaya dengan keahlian evaluasi pendidikan, yang kedua adalah Dr. Waspodo Tjipto Subroto, M.Pd., Pakar atau ahli pendidikan IPS dan Ekonomi, juga dari Universitas Negeri Surabaya. Kedua Ahli tersebut dipilih berdasarkan kepakaran beliau yang dibutuhkan dalam isi maupun konstruk instrumen penelitian ini.

Tabel 1.

Validitas Perangkat Secara Umum

\begin{tabular}{|c|c|c|c|c|}
\hline $\begin{array}{l}\mathrm{N} \\
\mathrm{o} .\end{array}$ & $\begin{array}{c}\text { Nama } \\
\text { Perangkat }\end{array}$ & $\begin{array}{c}\text { Validasi } \\
\text { oleh Ahli }\end{array}$ & $\begin{array}{c}\text { Uji Coba } \\
\text { I } \\
\end{array}$ & Uji Coba II \\
\hline 1 & RPP & $\begin{array}{l}\text { Layak } \\
\text { digunakan }\end{array}$ & & \\
\hline 2 & LKS & $\begin{array}{l}\text { Layak } \\
\text { digunakan }\end{array}$ & & \\
\hline 3 & $\begin{array}{l}\text { Asesmen } \\
\text { Penilaian } \\
\text { Sikap }\end{array}$ & $\begin{array}{l}\text { Layak } \\
\text { digunakan }\end{array}$ & $\begin{array}{l}23 \text { dari } 30 \\
\text { butir item } \\
\text { valid } \\
(77 \%)\end{array}$ & $\begin{array}{l}27 \text { dari } 30 \\
\text { butir item } \\
\text { valid }(90 \%)\end{array}$ \\
\hline 4 & $\begin{array}{l}\text { Asesmen } \\
\text { Penilaian } \\
\text { Pengetahu } \\
\text { an }\end{array}$ & $\begin{array}{l}\text { Layak } \\
\text { digunakan }\end{array}$ & $\begin{array}{l}9 \text { dari } 10 \\
\text { item valid } \\
(90 \%)\end{array}$ & $\begin{array}{l}10 \text { dari } 10 \\
\text { butir item } \\
\text { valid } \\
(100 \%)\end{array}$ \\
\hline 5 & $\begin{array}{l}\text { Asesmen } \\
\text { Penilaian } \\
\text { Keterampi } \\
\text { lan }\end{array}$ & $\begin{array}{l}\text { Layak } \\
\text { digunakan }\end{array}$ & $\begin{array}{l}7 \text { dari } 7 \\
\text { butir item } \\
\text { valid } \\
(100 \%)\end{array}$ & $\begin{array}{l}7 \text { dari } 7 \\
\text { butir item } \\
\text { valid } \\
(100 \%)\end{array}$ \\
\hline
\end{tabular}

Selain validitas, salah satu syarat instrumen yang baik harus reliabel (andal). Hasil analisis pada penelitian ini menunjukan bahwa instrumen yang dikembangkan memiliki reliabilitas yang baik, simpulan tersebut didukung oleh data-data empirik selama uji coba. Perlu diketahui bahwa Reliabilitas merupakan konsistensi dan ketelitian suatu instrumen, dalam hal ini adalah instrumen authentic assessment. Ada tiga perangkat utama pada penelitian ini yang membutuhkan pengujuan realibilitas secara empiric, yaitu perangkat peniaian sikap, pengetahuan, dan keterampilan. Masing-masing perangkat memiliki metode pengujian yang berbeda-beda.

Hasil pengujian ketiga instrumen berbeda-beda. Berdasarkan data dan hasil pembahasan peneliti dan pembimbing, perbedaan tersebut dipengaruhi oleh jumlah partisipan atau subjek penelitian, waktu penelitian, serta kemampuan partisipan dalam hal ini adalah siswa.

Pertama, jumlah siswa pada uji coba 1 sebanyak 12 siswa, setelah melalui penghitungan statistik, koefisien realibilitas pada uji coba tersebut tergolong tinggi (bisa dilihat pada tabel di bawah). Kemudian pada Uji Coba ke 2, siswa sebanyak 25, realibilitas perangkat sedikit menurun, kesimpulan ini mengandung arti bahwa jumlah partsipan berpengaruh pada hasil hitung realibiitas.

Kedua, waktu penelitian. Diketahui bersama bahwa tiap instrumen mempunyai waktu tersendiri sesuai dengan tingkat kesukaran, jumlah serta bentuk soal yang digunakan. Instrumen yang tidak seimbang antara beban dan waktu menyebabkan hasil yang tidak memuaskan. Dalam uji coba pertama, waktu antara pre test dan post tes tidak terlalu lama, sehingga siswa masih banyak mengingat isi soal, sehingga keajegan dalam menjawab soal tersebut cukup tinggi. Berbeda dengan uji coba ke dua, jarak antara uji pre tes dan pos tes cukup lama, sehingga banyak siswa yang lupa isi soal tersebut.

Ketiga, kemampuan dalam kelompok. Makin berbeda kemampuan siswa dalam suatu kelas, maka semakin tinggi realibilitas suatu instrumen. Kemudian, apabila suatu instrumen diberikan kepada kelas yang sama, maka realibilitasnya lebih rendah dibandingkan apabila instrumen tersebut diberikan pada kelas yang berbeda. Hal ini juga terjadi pada penelitian ini. Siswa pada uji coba ke 1 merupakan kelas yang dibentuk dengan komposisi yang proporsional oleh peneliti, dimana siswa merupakan yang teratas, empat sedang, dan empat terbawah. Variasi kemampuan ini berdampak pada hasil realibilitas yang tinggi pada uji coba pertama.

Tabel 3.

Reliabilitas Perangkat Secara Umum

\begin{tabular}{llllll}
\hline No & $\begin{array}{l}\text { Nama } \\
\text { Perangkat }\end{array}$ & Uji Coba I & \multicolumn{2}{l}{ Uji Coba II } \\
\hline 1 & Asesmen & 0,928 & - & 0,781 & - \\
& Penilaian & Memiliki & Memiliki & \\
& Sikap & Reliabilitas & reliabilitas & \\
& & yang sangat & yang tinggi & \\
& & tinggi & & \\
2 & Asesmen & 0,63 & - & 0,68 & - \\
& Penilaian & Memiliki & & Memiliki & \\
& Pengetahu & Reliabilitas & & Reliabilitas & \\
& an & yang cukup & & yang cukup & \\
& Asesmen & 0,635 & - & 0,610 & - \\
& Penilaian & Memiliki & & Memiliki & \\
& Keterampil & Reliabilitas & & Reliabilitas & \\
& an & yang cukup & & yang cukup & \\
\hline
\end{tabular}

Setelah reliabilitas, salah satu sarat instrumen yang baik yaitu praktis. Beberapa pegangan yang dapat dijadikan patokan suatu instrumen dikatakan praktis adalah (1) biaya yang diguankan tidak terlalu tinggi; (2) mudah diadministrasikan; (3) mudah diskor; (4) mudah 
diinterpretasikan; (5) waktu yang dipakai tepat dan tidak terlalu lama.

Untuk mengetahui ketercapaian lima indikator di atas, peneliti menyusun instrumen penelitian berupa angket yang ditujukan kepada Guru sebagai evaluator pembelajaran di kelas. Guru, dalam hal ini adalah responden, juga memberi masukan selain dari apa yang ada pada butir instrumen angket. Peneliti meminta 2 orang guru sebagai Responden di masing-masing fase penelitian. Guru tersebut adalah seorang guru kelas pada kelas tersebut, dan seorang guru mata pelajaran lain. Posisi responden tidak sama seperti validator, artinya responden tidak memiliki porsi untuk memberikan justifikasi atas kelayakan instrumen, mereka berada pada posisi pengguna (konsumen), sehingga respon yang diberikan berdasarkan pengalaman empirik mereka berpartisipasi menggunakan produk perangkat asesmen ini. Selain itu, responden tidak memberi respon secara rinci per jenis sub perangkat dan per item seperti validator, tetapi mereka memberi respon secara keseluruhan perangkat.

Seperti yang data yang telah dikemukakan pada bab sebelumnya, bahwa pada Uji Coba I, perangkat dinilai sudah praktis, namun demikian masih ditemukan beberapa catatan. Catatan pertama, bahwa dalam mengamati sikap siswa, jika hanya satu orang guru kelas, maka tidak dapat secara adil mengamati siswa satu per satu, maka kembali asumsi siswa bersikap baik yang lebih dominan. Kedua, bahwa lingkup penggunaan perangkat ini hanya pada $1 \mathrm{sub}$ tema, maka dari itu sinkronisasi dengan seri perangkat yang lain juga harus diperhatikan. Ketiga, berdasarkan respon pada angket, responden kompak mengatakan bahwa mereka kurang setuju bahwa perangkat penilaian semacam ini siap dibuat oleh guru-guru lain, karena menurut mereka proporsi waktu persiapannya lebih banyak daripada ketersediaan waktu seorang guru kelas dengan berbagai tugas lainnya.

\section{SIMPULAN DAN SARAN}

Berdasarkan hasil kajian pustaka, pertimbangan ahli, dan pengujian empiris, maka didapat disimpulkan bahwa (1) Produk berupa hasil pengembangan Authentic Assessment sebagai fungsi penilaian formatif valid digunakan pada pembelajaran IPS di Kelas IV SD Semester II, dengan Tema Lingkunganku; (2) Produk berupa hasil pengembangan Authentic Assessment sebagai fungsi penilaian formatif memiliki keandalan/realibilitas yang baik digunakan pada pembelajaran IPS di Kelas IV SD Semester II, dengan Tema Lingkunganku; (3) Produk berupa pengembangan Authentic Assessment sebagai fungsi penilaian formatif memiliki kepraktisan yang baik digunakan pada pembelajaran IPS di Kelas IV SD Semester II, dengan Tema Lingkunganku.

Saran yang bisa diberikan peneliti adalah (1) Dalam menyusun instrumen penilaian, validitas atau kesahihan alat penilaian sangat ditentukan oleh isi atau substansi item soal, oleh karena itu dalam membuat soal guru sebaiknya menghindari cara-cara lama, seperti membuat soal dahulu kemudian mensinkronkan kisi-kisinya, guru atau peneliti harus secara berjenjang menyusun instrumen soal sesuai kaidah-kaidahnya. (2) Keandalan sebuah asesmen bisa berbeda-beda di setiap seting maupun partisipannya, oleh karena itu peneliti perlu memiliki wawasan yang luas mengenai metodologi penentuan realibilitas soal. Tes acuan norma dan kriteria memiliki asumsi dan tujuan yang berbeda, hal tersebut berdampak pada metode penentuan tingkat reliabilitasnya. (3) Kepraktisan suatu tes bisa ditentukan oleh cost pengadaan dan pelaksanaan (waktu), oleh karena itu perlu perhitungan dengan memperhatikan proporsi waktu dan biaya yang ditimbulkan dalam melaksanakan sebuah penilaian.

\section{DAFTAR PUSTAKA}

Ibrahim, M. 2005. Assessment Berkelanjutan. Surabaya: Unesa University Press.

Kemdikbud. 2015. Pedoman Penilaian Untuk Sekolah Dasar. Jakarta: Direktorat Pendidikan Dasar dan Menengah.

Kemp, J. E. 1994. Designing Effective Instruction. Ontario: Maxwell Macmillan Canada.

Kunandar. 2015. Penilaian Autentik: Penilaian Hasil Belajar Peserta Didik Berdasarkan Kurikulum 2013. Jakarta: Rajawali Pers.

Peraturan Menteri Pendidikan dan Kebudayaan Republik Indonesia No. 66 Tahun 2013. Tentang Standar Penilaian Pendidikan.

Peraturan Menteri Pendidikan dan Kebudayaan Republik Indonesia No. 53 Tahun 2015 Tentang Penilaian Pendidikan Oleh Pendidik.

Peraturan Pemerintah Republik Indonesia No. 32 Tahun 2013 Tentang Perubahan Atas Peraturan Pemerintah No. 19 Tahun 2005 Tentang Standar Nasional Pendidikan.

Popham, W. J. 2008. Transformative Assessment. Virginia: Association for Supervision and Curriculum Development (ASCD).

Popham, W. J. 2011. Transformative Assessment In Action. Virginia: ASCD.

Rayment, T. 2006. 101 Essentiial list of Assessent. London: Continuum.

Riyanto, Yatim. 2007. Metodologi Penelitian 
Pendidikan Kualitatif dan Kuantitatif. Surabaya:

Unesa University Press. . 2009. Paradigma Baru Pembelajaran: Sebagai Referensi Bagi Guru/Pendidik Dalam Implementasi Pembelajaran Yang Efektif dan Berkualitas. Jakarta: Kencana.

Stringer, Ernest T \& Christensen LM And Baldwin S C. 2010. Integrating Teaching, Learning, and Action Research. California: SAGE Publication.

Thiagarajan, S \& Semmel, DS And Semmel, Melvyn. 1974. Instructional Development For Training Teachers Of Execptional Children. Indiana: Indiana University Bloomington.

Uno, Hamzah B dan Koni. 2013. Assessment Pembelajaran. Jakarta: Rineka Cipta. 